\title{
HARDNESS SURVEY OF COLD-WORKED \\ AND HEAT-TREATED \\ JBK-75 STAINLESS STEEL ALLOY
}

Ross J. Jackson

Robert L. Lucas

Research and Development, MATERIALS TECHNOLOGY

PHYSICAL METALLURGY GROUP

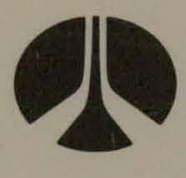
Rockwell International

Atomics International Division

Rocky Flats Plant

P.O. Box 464

Golden, Colorado 80401

U.S. ENERGY RESEARCH AND DEVELOPMENT ADMINISTRATION

CONTRACT EY-76-C-04-3533 


\section{DISCLAIMER}

This report was prepared as an account of work sponsored by an agency of the United States Government. Neither the United States Government nor any agency Thereof, nor any of their employees, makes any warranty, express or implied, or assumes any legal liability or responsibility for the accuracy, completeness, or usefulness of any information, apparatus, product, or process disclosed, or represents that its use would not infringe privately owned rights. Reference herein to any specific commercial product, process, or service by trade name, trademark, manufacturer, or otherwise does not necessarily constitute or imply its endorsement, recommendation, or favoring by the United States Government or any agency thereof. The views and opinions of authors expressed herein do not necessarily state or reflect those of the United States Government or any agency thereof. 


\section{DISCLAIMER}

Portions of this document may be illegible in electronic image products. Images are produced from the best available original document. 


\section{LEGAL NOTICE}

This report was prepared as an account of work sponsored by the United States Government. Neither the United States nor the Energy Resedich and Development Administration, nor any of their employees, nor any of their contractors, subcontractors, or their employees, makes any warranty, expressed or implied, or assumes any legal liability or responsibility for the accuracy, completeness or usefulness of any information, apparatus, product or process disclosed, or represents that its use would not infringe privately owned rights.

Printed in the United States of America

Available from the

National Technical Information Service

U. S. Department of Commerre.

Springfield, Virginia 22161

Price: Printed Copy $\$$ Microfiche $\$ 3.00$

Price Is Subject to Change Without Notice 


\title{
HARDNESS SURVEY OF COLD-WORKED
}

AND HEAT-TREATED

\section{JBK-75 STAINLESS STEEL ALLOY}

Ross J. Jackson

Robert L. Lucas

\author{
Research and Development, \\ MATERIALS TECHNOLOGY \\ PHYSICAL METALLURGY GROUP
}

\author{
SUBJECT DESCRIPTORS \\ Stainless Steels \\ Heat Treatments \\ Cold Working \\ Hardness \\ Precipitation Hardening
}

ROCKWELL INTERNATIONAL ATOMICS INTERNATIONAL DIVISION ROCKY FLATS PLANT

P.O. BOX 464

GOLDEN, COLORADO 80401

Prepared under Contract EY-76-C-04-3533 for the

Albuquerque Operations Office
This seport was prepared as an eccount of work sponsored by the United States Government. Neither the United States nor the United States Energy Rescarch and Development Admusist this, not any or theis employecs, not any of their contraciors, warranty, express or implied, us assuuses aus loyal liability or responsibility for the accuracy, completeness or usefulness of any information, apparatus, product or process disclosed, or represents that its use would not infringe privately owned rights.

$-$

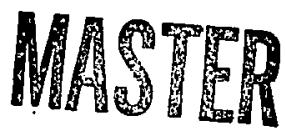


RFP-2492

THIS PAGE

\section{WAS INTENTIONALLY LEFT BLANK}




\section{CONTENTS}

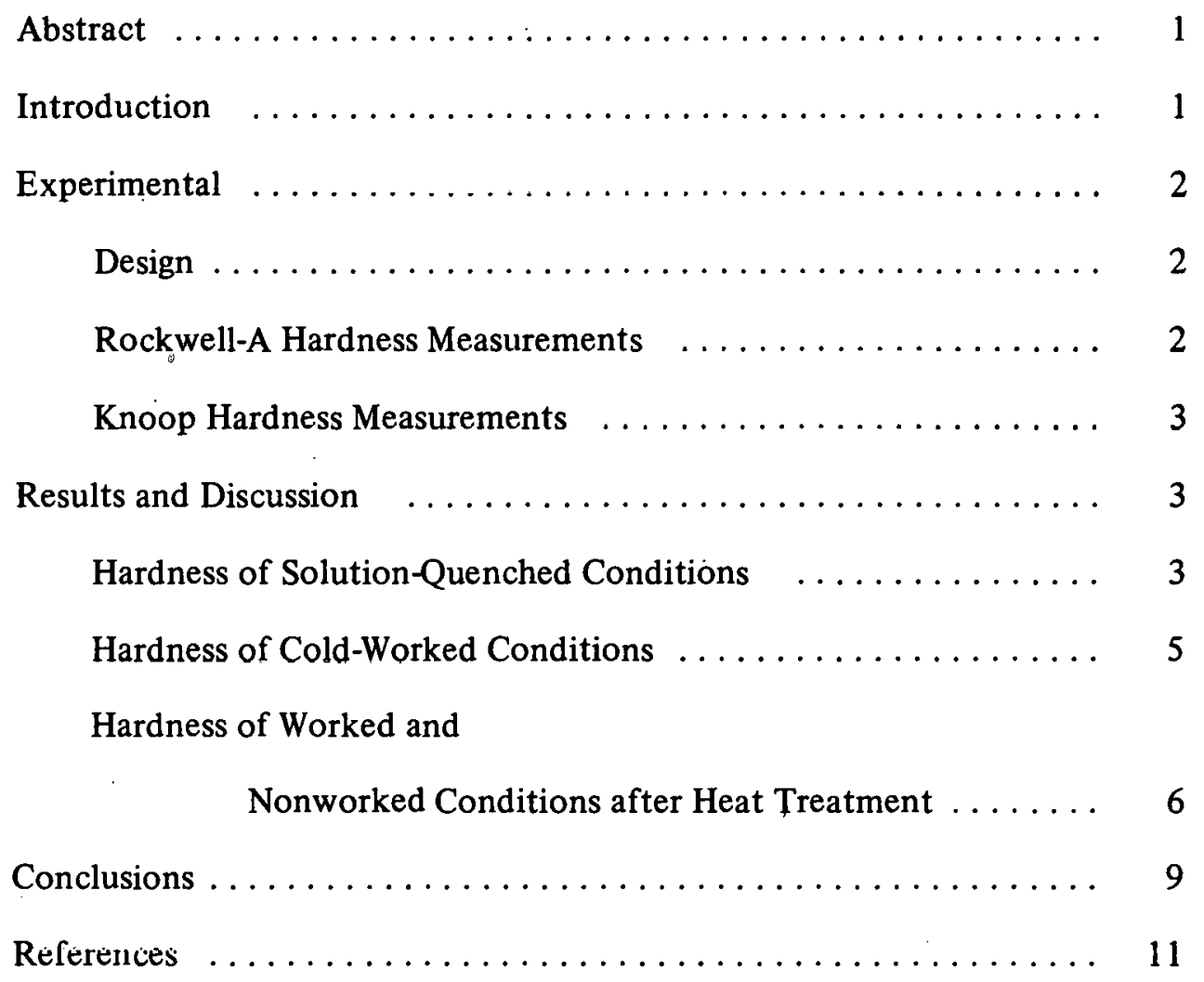


RFP-2492

THIS PAGE

\section{WAS INTENTIONALLY LEFT BLANK}




\title{
HARDNESS SURVEY OF COLD-WORKED AND HEAT-TREATED JBK-75 STAINLESS STEEL ALLOY
}

\author{
Ross J. Jackson and Robert L. Lucas
}

\begin{abstract}
The alloy JBK-75, an age-hardenable austenitic stainless steel, is similar to commercial A-286, but has certain chemistry modifications to improve weldability and hydrogen compatibility. The principal changes are an increase in nickel and a decrease in manganese with lower limits on carbon, phosphorus, sulfur, silicon, and boron. In this study, the effects of solutionizing time and temperature, quench rate, cold working, and the effects of cold working on precipitation kinetics were examined. Findings show that the solutionizing temperature has a moderate effect on the as-quenched hardness, while times greater than that required for solutionizing do not significantly affect hardness. Quench rate was found to have a small effect on as-quenched hardness, however, hardness gradients did not develop in small bars. It was found that JBK-75 can be significantly strengthened by cold working. Cold working alone produced hardness increases from Rockwell-A 49 to $R_{A} 68$. A recovery-related hardness change was noted on heat treating at 300 and $400{ }^{\circ} \mathrm{C}$ for both as-quenched and as-worked JBK-75. Significant age-hardening was obscrved at temperatures as low as $500^{\circ} \mathrm{C}$ for as-worked metal.
\end{abstract} Aging at $600{ }^{\circ} \mathrm{C}$ resulted in maximum hardness in the 75 percent worked sample at about 6 hours $\left(R_{A}\right.$ 73.5) while the 50 percent worked sample was near maximum hardness $\left(R_{A} 72.5\right)$ after seven days. The 25 and 0 percent worked samples were considerably underaged after seven days. Similar type kinetic data were obtained for worked and nonworked metal at $650,700,800,850,900$, 1000 , and $1100^{\circ} \mathrm{C}$ for times from 10 minutes to 10,000 minutes (6.7 days). The overall purpose of the hardness survey was to better define the effects of cold work on the stress-relieving range, coherent precipitation range, incoherent precipitation range, recrystallization range, solutionizing range, and grain-growth range.

\section{INTRODUCTION}

Modified A-286 (JBK-75), an age-hardenable austenitic stainless steel, is a more weldable alloy achieved by minor adjustments in the chemistry of commercial A-286 $(1,2){ }^{1}$ The chemical compositions of JBK-75 and commercial A-286 are shown in Table I. Both A-286 and its modification, JBK-75, are strengthened by precipitation of the gamma prime $\left(\gamma^{\prime}\right)$ phase $(3,4,5)$ familiar in nickel-base superalloys. Achievable yield strengths are in the range 700 to 800 megapascals (MPa) (about 100 to 120 thousand pounds per square inch) (6).

${ }^{1}$ Numerals in parentheses relate to references at end of text.

TABLE I. Chemical composition of JBK.75 and commercial A-286 stainless steels.
JDK-75

(Modified A-286)

(weight percent)

13.5 to 16.0

29.0 to 31.0

1.0 to 1.5

0.30 maximum

0.01 to 0.03

0.010 maximum

0.010 maximum

0.20 maximum

0.1 lo 0.5

2.0 to 2.3

0.15 to 0.35

0.001 maximum

70 ppm maximum 
A literature survey uncovered only three journal articles and one patent dealing with Modified A-286. Brooks and Krenzer (7) studied high temperature phase equilibria in A-286 stainless steel and the role of the individual alloying elements on fusion-zone (weld-metal) cracking of A-286. Results also indicated that the composition of the high temperature grain boundary phase thought to be responsible for heat-affected-zone (HAZ) microfissuring in commercial A-286 is more complex than that reported in the literature, and that a more weldable alloy can be achieved by minor adjustments in chemistry. Brooks (2) further investigated the HAZ cracking mechanisms in A-286 using spot varestraint and hot-ductility testing techniques. The two studies led to a U.S. Patent (8) for Modified A-286. Thompson and Brooks (9) studied the hydrogen performance of eleven chemistry modifications of A-286. They found the most beneficial changes in composition being removal of manganese (Mn) and a 5 percent increase in nickel (Ni). That change resulted in only an 11 percent loss in reduction in area after hydrogen charging, a value comparable to many single-phase austenitic steels of lower strength.

\section{EXPERIMENTAL}

\section{Design:}

The experimental approach was threefold: (a) determine the hardness of solution-quenched material; (b) determine the hardness of cold-worked material; and (c) determine the hardness of worked and unworked metal after heat treating in the temperature range of 300 to $1100{ }^{\circ} \mathrm{C}$ for times of 10 to 10,000 minutes.

To determine the hardness of solution-quenched material, alloys were held various lengths of times at 900,1000 , and $1100^{\circ} \mathrm{C}$ and water quenched to room temperature. To determine the hardness of cold-worked metal, alloys were cold-rolled to $5,10,15,20,25,30,40,50,60,75$, and 90 -percent reductions in thickness.

To obtain the hardness of worked and unworked metal after aging, solution-quenched samples were cold-reduced $0,25,50$, and 75-percent in thickness.
These were then isothermally aged for 10,100 , 1000 , and 10,000 minutes at temperatures of 400 , $500,600,650,700,800$, and $850^{\circ} \mathrm{C}$. When additional data were needed, times of 40,400 , and 4000 minutes were also included. All samples were water-quenched from the aging temperature.

\section{Rockwell-A Hardness Measurements:}

The Rockwell hardness test is an indentation test using a differential-depth measurement. The Rockwell-A method of hardness testing consists of measuring the increment of depth of a diamondcone (Brale) penetrator that is forced into the metal by a primary [ 10 kilograms ( $\mathrm{kg})$ ] and secondary $(60 \mathrm{~kg})$ load. The testing and analysis procedures are described by Kehl (10). The Rockwell-A scale was chosen for this study due to its low major load, and to its wide range, i.e., Rockwell $A$ measures on one scale the extremely soft solutionquenched condition and the extremely hard worked and aged condition.

The Rockwell-A surface measurements on rolled sheet or plate were on the longitudinal face. The only surface preparation the longitudinal face received was a degreasing wash followed by a 30 second electropolish in a 60:40 volume percent mixture of orthophosphoric acid and water mixture lo brighlen the surface. All hardness indents were well away frum any edge effecils [indents no closer than 3 millimetres (mm) to edge]; end effects (indents no closer than $15 \mathrm{~mm}$ to ends of rolled sheet); thickness effects (thickness greater than 10 times the indent diameter); and, other indentation effects (indentation separations greater than 10 times the indent diameter).

The Rockwell-A measurements to determine centerline hardness were on polished and etched longtransverse faces. After cold rolling, the longtransverse face was sheared along a centerline parallel to the rolling direction. The sheared longtransverse face was then mounted in an epoxy resin for grinding and polishing. Three millimetres of metal were removed by grinding on 60 -grit siliconcarbon $(\mathrm{SiC})$ paper under a heavy flow of cold water. The sample was then mechanically polished and electrolytically etched by a procedure described in the next section. All Rockwell-A hardness values listed are an average of at least five indents. 


\section{Knoop Hardness Measurements:}

The Knoop hardness test is an indentation test where the number obtained is equal to the applied load divided by the elastically unrecovered projected area of the impression. The testing and analysis procedures are discussed by Kehl (10). In this study, the Knoop hardness measurements in all cases were taken on polished and etched surfaces using a 500-gram load, and were normally on the long-transverse face. The long axis of the Knoop indenter was in all cases parallel to the rolling direction. The position of the hardness indents was along or near the centerline of the specimen thickness well away from any end effects. Each Knoop hardness value listed is an average of at least five indents.

The sample preparation procedure for Knoop hardness testing is as follows. After mechanical or thermal treatment (or both), the samples were mounted in an epoxy resin that required curing at about $68^{\circ} \mathrm{C}$ for 20 hours. One-eighth inch $(3.2 \mathrm{~mm})$ of metal was removed from the long-transverse face by grinding on 60-grit $\mathrm{SiC}$ paper on a rotary wheel under a steady flow of cold water. This was followed by water-cooled, rotary-grinding, for 1 to 2 minutes each on 320, 400, and 600-grit SiC papers. Initial polishing was for 20 hours on a vibratory unit with one-micrometre $(\mu \mathrm{m})$ diamond on a Nylon cloth backed by a high-napped synthetic cloth with an oil-free kerosene as the carrier. Intermediate polishing was with a $0.025-\mu \mathrm{m}$ diamond using the same parameters as with the $1-\mu \mathrm{m}$ diamond. Final polish was with a $0.05-\mu \mathrm{m}$ alumina, water slurry on a high-napped cloth for 1 to 2 minutes. After each polishing step, the samples were sonically cleaned with an aqueous soap solution and then warm water rinsed with a cotton swab. The samples were then electroetched for 30 to 90 seconds in a 10 percent oxalic acid solution initially at room temperature.

\section{RESULTS AND DISCUSSION}

\section{Hardness of Solution-Quenched Conditions:}

The JBK-75 alloy, similar to commercial A-286, develops its relatively high strength-to-weight ratio through heat treatment. The first step is a solution heat treatment in the range of 900 to $1010^{\circ} \mathrm{C}$ $\left(1650\right.$ to $1850^{\circ} \mathrm{F}$ ) for one to four hours; followed by a water or oil quench to room temperature.

The purposes of this step are to: (a) enhance ductility, (b) make the steel uniformily austenitic, and (c) condition the steel for subsequent precipitation hardening. The second step is an aging in the range of 650 to $760^{\circ} \mathrm{C}(1200$ to $1400^{\circ} \mathrm{F}$ ) for about 16 hours; followed by an air cool to room temperature. This step is to precipitation harden the alloy to near maximum toughness.

The solutionizing treatment is primarily to dissolve the intermetallic $\left(\mathrm{Ni}_{3} \mathrm{Ti}\right)$ platelets which form on overaging. The $\mathrm{Ni}_{3} \mathrm{Ti}$ phase is the equilibrium phase of the coherent transition precipitate responsible for age hardening of this alloy. Since the amount of titanium and nickel in solid solution determines the extent of age hardening, it follows that the solutionizing of all $\mathrm{Ni}_{3} \mathrm{Ti}$ phase is important.

The effect of solutionizing time and temperature is shown in Figures 1 and 2. In Figure 1, the samples were first water-quenched after one hour at $985^{\circ} \mathrm{C}$, then cold-rolled to 25 percent reduction in thickness, followed by isothermal aging at 900 , 1000 , and $1100^{\circ} \mathrm{C}$ for 100,1000 , and 10,000 minutes and water quenched. For times of 100 minutes and greater, the solution-quenched hardness was not significantly dependent on time but was dependent on solutionizing temperature. Samples solutionized at 900,1000 , and $1100^{\circ} \mathrm{C}$ gave values of 150,141 , and 134-Knoop, respectively, or $46.5,44.5$, and $42.8 R_{A}$, respectively.

The hardness values shown in Figure 2 were for samples cold-rolled to 50 percent reduction in thickness, then isothermally aged at 850,900 , and $1000^{\circ} \mathrm{C}$ for 100,1000 , and 10,000 minutes, respectively. Here again, the solution quenched hardness was not significantly time dependent, but was temperature dependent. The JBK-75 samples solutionized at 850,900 , and $1000^{\circ} \mathrm{C}$ gave values of 198, 150, and 146-Knoop, respectively, or 55.1, 46.5 , and $45.7-R_{A}$, respectively.

Specimen size does have an effect on the solutionquenched hardness. For example, the bar shown in 


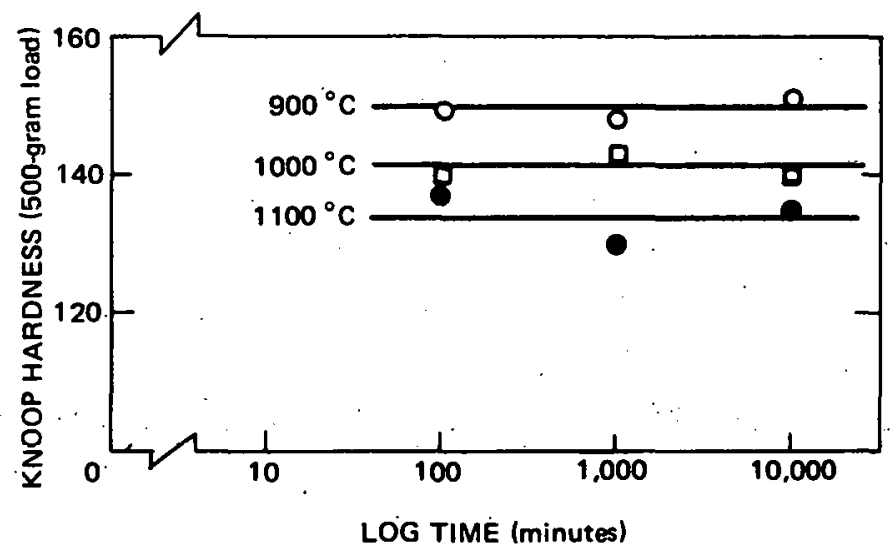

FIGURE 1. Knoop hardness values for JBK-75 alloy (1.85-welght percent titanium) after solutionizing at 900 , 1000 , and $1100{ }^{\circ} \mathrm{C}$ for times of 100,1000 , and 10.000 minutes. The samples were cold-rolled to 25 percent reduction in thickness, prior to solutionizing. The indentations were along the centerline of the long-transverse face.

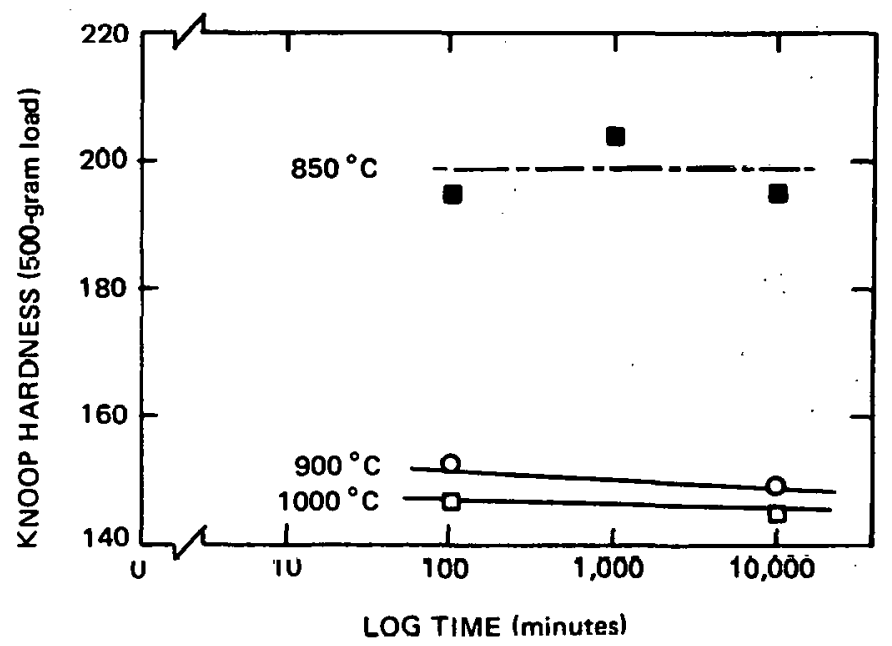

FIGURE 2. Knoop hardness values for JBK-75 alloy (1.85-weight percent titanium) after solutionizing at 850 , 900 , and $1100{ }^{\circ} \mathrm{C}$ tor times of 100,1000 , and 10.000 minutes. The samples were cold-rolled to 50 percent reduction in thickness prior to solutionizing. The indentations were along the centerline of the long-transverse face.

Figure 3 was water-quenched after one hour at $925^{\circ} \mathrm{C}$. This bar had a surface hardness of RockwellA 53 (Knoop 184), and a center hardness of $R_{A} 49$ (Knoop 160). Figure 3 also shows the

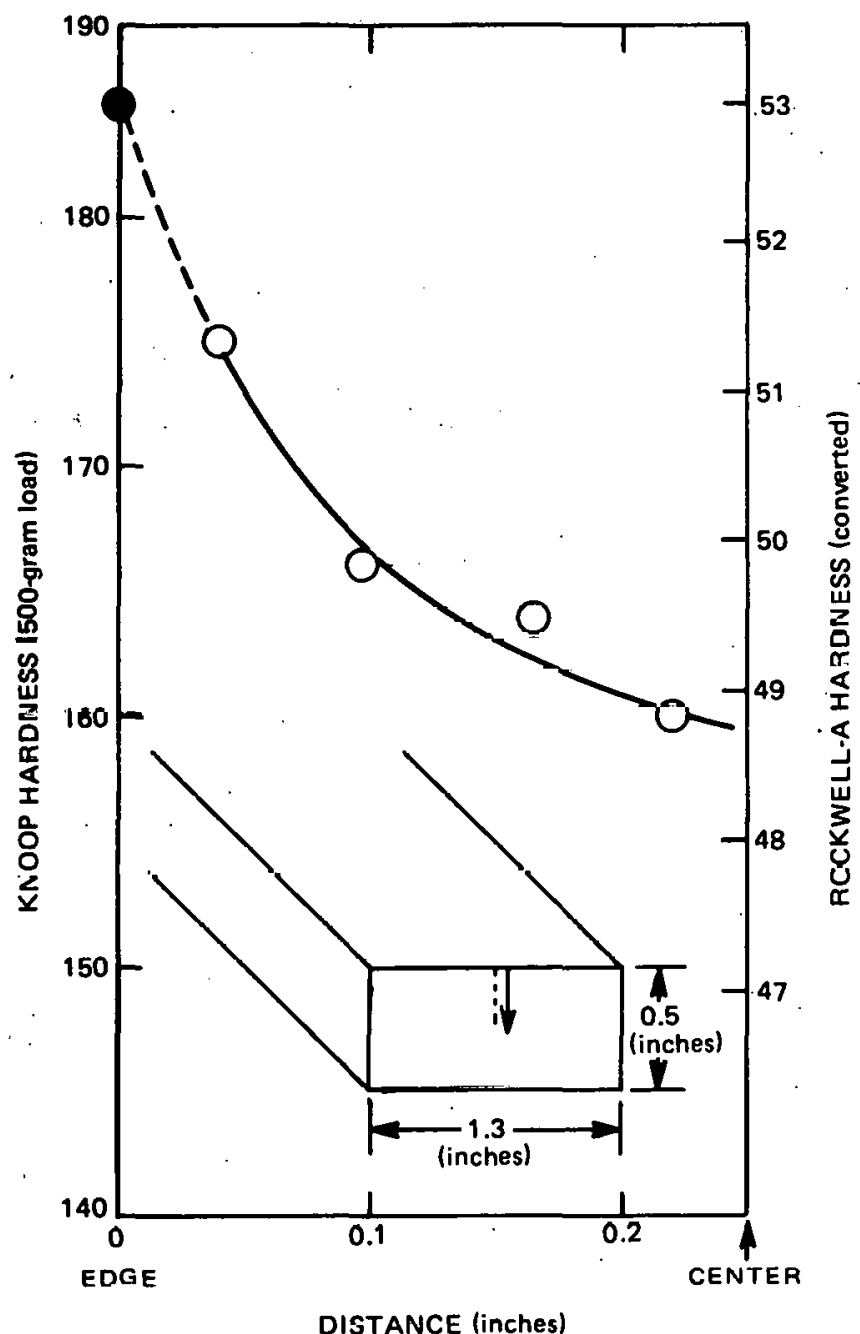

FIGURE 3. Center-to-edge Knoop hardness variation in one-half inch thick bar of JBK-75 (1.85-weight perrent titanium) water-quenched, after solutionizing one hour at $925^{\circ} \mathrm{C}\left(1697^{\circ} \mathrm{F}\right)$.

positional hardness variation in a solution-quenched bar. The reason for the center-to-edge variation in hardness is not known. but is not due to martensitc formation as in steels. The solution-quenched hardness values discussed in the previous two paragraphs were from bars smaller in thickness, and had lower centerline hardness values. This may be due to the shorter time for homogenization in the large bar and, hence, incomplete solution of the $\mathrm{Ni}_{3} \mathrm{Ti}$ phase. 
TABLE II. The hardness and hardness profiles of sectioned water-quenched, oil-quenched, and airquenched JBK-75. The sample size before sectioning was 2.5 by 2.5 by 1.3 -centimetres. The solutionizing time and temperature was 100 minutes at $950^{\circ} \mathrm{C}$.

\begin{tabular}{|c|c|c|c|c|}
\hline \multicolumn{2}{|c|}{ Location of Indent } & \multicolumn{3}{|c|}{ Knoop Hardness, 500-Gram Load } \\
\hline Position & $\begin{array}{c}\text { Distance } \\
\text { (millimetres) }\end{array}$ & $\begin{array}{l}\text { Water } \\
\text { Quench }\end{array}$ & $\begin{array}{c}\text { Oil } \\
\text { Quench }\end{array}$ & $\begin{array}{c}\text { Air } \\
\text { Quench }\end{array}$ \\
\hline \multicolumn{5}{|c|}{$\begin{array}{c}\text { Edge-to-Center } \\
\text { (diameter fraction) }\end{array}$} \\
\hline 0.05 & 0.7 & 163 & 166 & 157 \\
\hline 0.13 & 1.7 & 158 & 169 & 166 \\
\hline 0.20 & 2.6 & 155 & 164 & 165 \\
\hline 0.28 & 3.6 & 157 & 154 & 164 \\
\hline 0.35 & 4.5 & 157 & 157 & 165 \\
\hline 0.43 & 5.6 & 158 & 151 & 157 \\
\hline $\begin{array}{l}0.50 \\
\text { (center) }\end{array}$ & 6.5 & 164 & 159 & (center) \\
\hline \multirow[t]{2}{*}{ Average } & & 158 & 160 & 164 \\
\hline & & (48.5 $\mathrm{R}_{f}$ & $\left(49.0 \mathrm{R}_{\mathrm{A}}\right.$ & $\left(49.5 R_{A}\right)$ \\
\hline
\end{tabular}

*For SI (metric) use: 25.4 millimetres and 2.54 centimetres $=1$ inch.

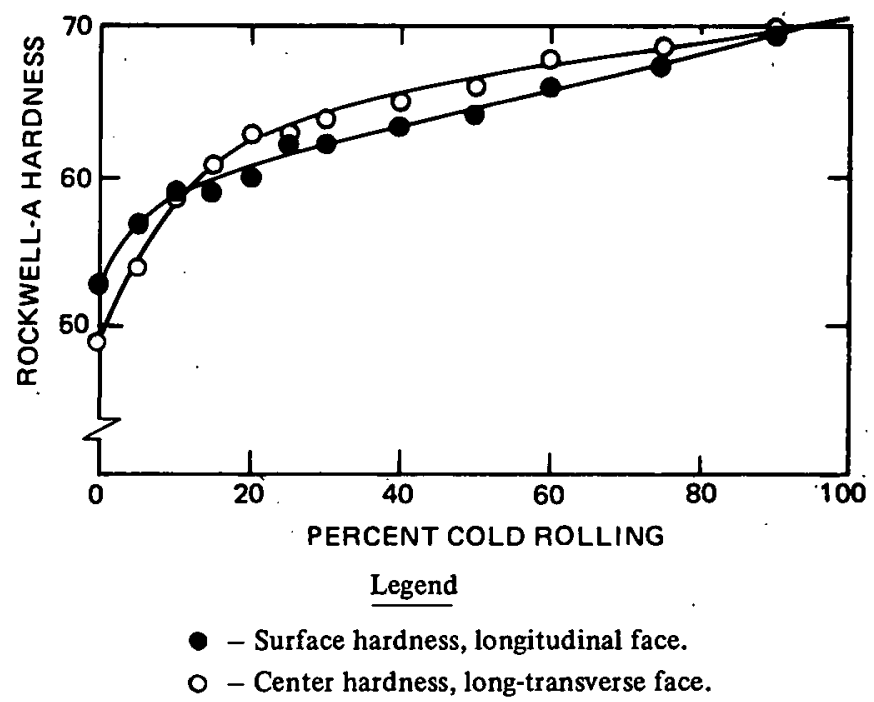

FIGURE 4. Comparison of Rockwell-A hardness values of the longitudinal face (surface) and longtransverse face (centerline) of room-temperature rolled JBK-75 (1.85-weight percent titanium).
To evaluate the effect of quench rate on hardness and hardness profiles, samples were water-quenched, oil-quenched, and air-quenched after 100 minutes at $950^{\circ} \mathrm{C}\left(1742^{\circ} \mathrm{F}\right)$. The samples were 2.5 by 2.5 by 1.3 -centimetres $(\mathrm{cm})$ (approximately 1 by 1 by 0.5 -inches) in size. After quenching, the samples were sectioned in such a manner that after removal of 0.125 inches $(3.2 \mathrm{~mm})$ of metal by grinding and polishing, the samples were half their original size, i.e., 1.0 by 0.5 by 0.5 -inches. The hardness values on traversing from edge-to-center are listed in Table II. From the table, one can conclude that a significant hardness gradient is not developed on air, oil, or water-quenching bars 1 by 1 by 0.5 inches in size. Table II also shows that the bar hardness is a function of cooling rate, i.e., the water-quenched alloy was softest ( $158 \mathrm{Knoop}$ or $R_{A} 48.5$ ), the oil-quenched alloy was intermediate in hardness ( 160 Knoop or $R_{A} 49.0$ ), while the air-quenched material was hardest (164 Knoop or $R_{A}$ 49.5).

\section{Hardness of Cold-Worked Conditions:}

As with other austenitic stainless steels, JBK-75 can be significantly strengthened by cold working. The cold-working treatment was cold-rolling $\left(24^{\circ} \mathrm{C}\right)$, and the measure was the percent reduction in thickness. Roll specds of 20 to 25 feet per minute ( 6 to 8 metres per minute) with reductions of about 30 mils $(0.75 \mathrm{~mm})$ per pass guaranteed that the working operation did not significantly heat the sample.

The surface and center hardness (Rockwell A) of cold-rolled sheet as a function of percent reduction in thickness is shown in Figure 4. Hardness increases from $R_{A} 49$ (Knoop 160) to $R_{A} 70$ (Knoop 390) are possible by cold working alone.

A center-to-edge variation in hardness was noted for the cold-worked material. Below 10 percent reduction in thickness, the surface is harder than the center which is the result of the positional variation in hardness of the solution-quenched condition. At about 10 percent reduction in thickness, there is a cross-over point, above which the center is harder than the surface. Above 
about 85 percent reduction in thickness, the center and surface hardness are about equal. The reason the center is harder than the surface from 10 to 85 percent reduction in thickness is unknown.

All cold-rolled $\left(24^{\circ} \mathrm{C}\right)$ samples were examined for martensite formation with a Magne-Gage $\AA$ and with a Severn Gage $\AA$. None of the rolled samples $(5,10$, $15,20,25,30,40,50,60,80$, and 90 -percent reduction in thickness) showed any indication of martensite formation. The JBK-75 alloy with 30 percent nickel should have a stable austenitic structure and the above results tend to verify this.

\section{Hardness of Worked and Nonworked Conditions after Heat Treatment:}

The heat-treating ranges for JBK-75 are roughly as fulluws:

\begin{tabular}{|c|c|}
\hline Stress-Relieving Range & 400 to $600^{\circ} \mathrm{C}$ \\
\hline Coherent Precipitation Range & 500 to $700{ }^{\circ} \mathrm{C}$ \\
\hline Incoherent Precipitation Range & 600 to $850^{\circ} \mathrm{C}$ \\
\hline R.ecrystallization Range & 800 to $900{ }^{\circ} \mathrm{C}$ \\
\hline Solutionizing Range & 850 to $1000{ }^{\circ} \mathrm{C}$ \\
\hline Grain-Gruwth Range & 800 to $1200{ }^{\circ} \mathrm{C}$ \\
\hline
\end{tabular}

The primary purpose of this study was to survey the heat-treating behavior of worked and unworked JBK-75 stainless steel in the temperature range of 300 to $1200^{\circ} \mathrm{C}$ at times of 10 to 10,000 minutes. The objective of this work was to generate data that would aid future studies designed to define the above listed heat-treating ranges.

Heat treatments were in tube-type electrical resistance furnaces. Temperature control and accuracy were in all cases better than $\pm 10^{\circ} \mathrm{C}$. Uncirculated air surrounded the samples during the soaking portion of the heat-treating cycle. The furnace was first stabilized at the desired temperature. The samples were then introduced in the hot furnace and allowed a six minute heat-up, furnacestabilization time. The sample was held for the desired length of time and then quickly removed from the furnace and immersed in a two-litre can of room temperature water.

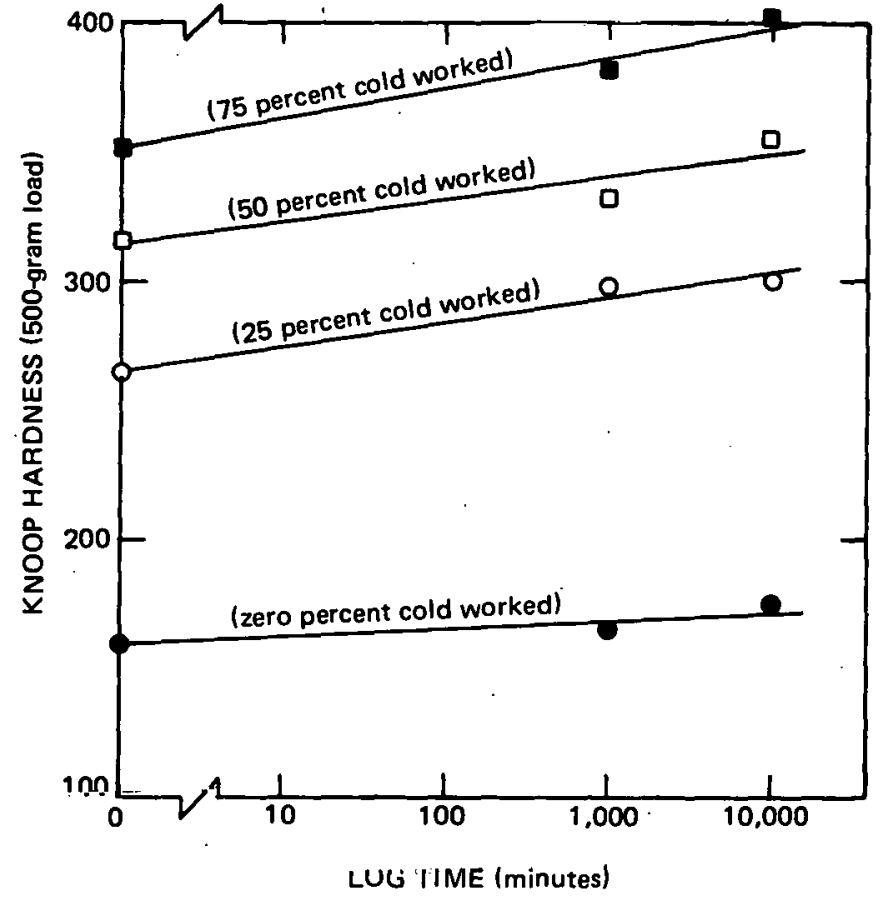

FIGURE 5. Knoop hardness values of worked and nonworked JBK-75 (1.85-weight percent titanium) after isothermal aging at $300^{\circ} \mathrm{C}\left(572^{\circ} \mathrm{F}\right)$, and after rolling at $23^{\circ} \mathrm{C}$.

The samples were roughly 0.7 inches $(18 \mathrm{~mm})$ in width and length. The thickness of the 0,50 , and 75-percent wnrked samples wao 0.130 inclies (3.3 11111), while the thickness of the 25 percent worked samples was 0.200 inches $(5.1 \mathrm{~mm})$.

The JBK-75 alloy is age-hardened by a mechanism wherein the titanium, nickel, and aluminum in solid solution precipitate as a titanium, aluminum, and nickel-bearing coherent precipitate referred to as gamma prime $\left(\gamma^{\prime}\right)\left(\mathrm{Ni}_{3} \mathrm{AlTi}\right)$. The stoichiometry of $\boldsymbol{\gamma}^{\prime}$ is not wcll-defined and the aluminumtitanium ratio is rather flexible. Upon overaging with its accompanying loss of coherency, the original $\gamma^{\prime}$ coherent precipitate is transformed to the noncoherent precipitate identified as $\mathrm{Ni}_{3} \mathrm{Ti}$ which form along fixed crystallographic planes. Thus, $\mathrm{Ni}_{3} \mathrm{Ti}$ is considered to be the equilibrium phase of the $\gamma^{\prime}$ coherent transition structure which is mainly responsible for the precipitation hardening of the JBK-75 alloy. 


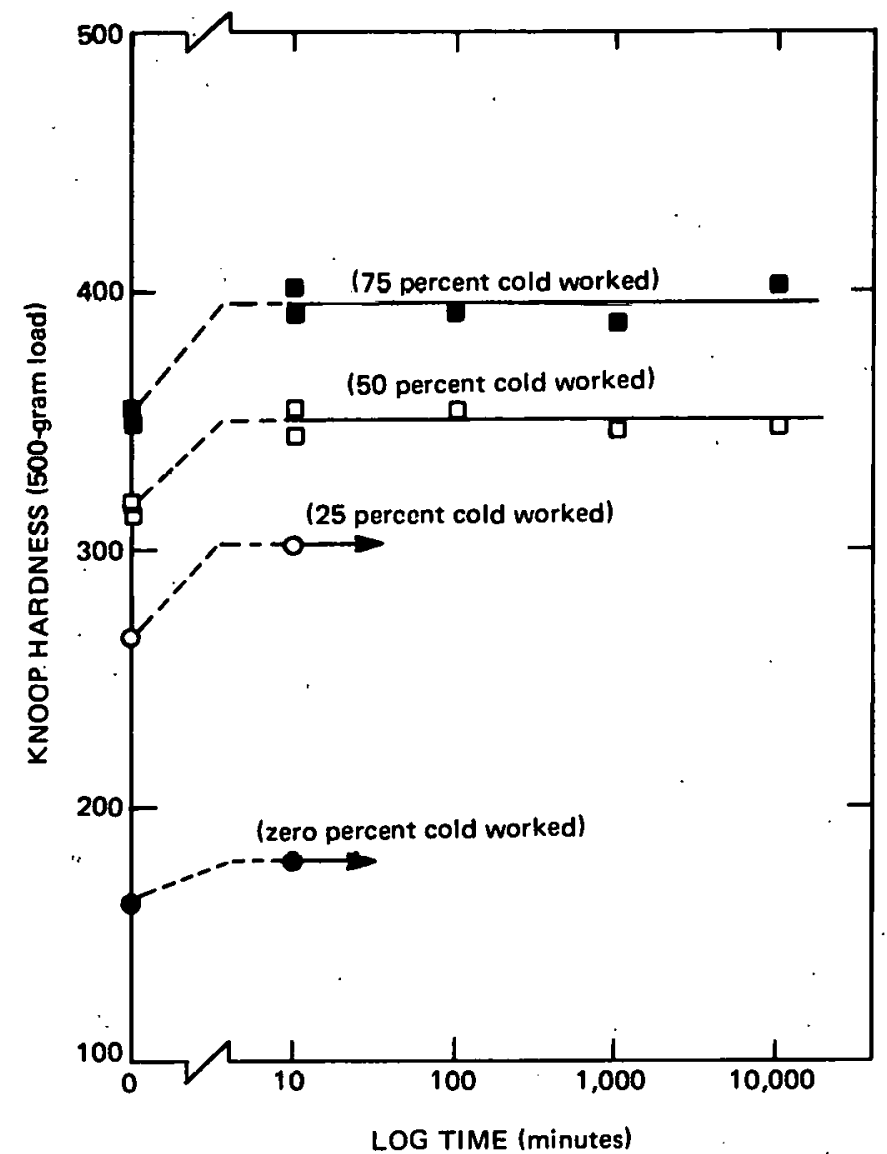

FIGURE 6. Knoop hardness values of worked and nonworked JBK-75 (1.85-weight percent titanium) after isothermal aging at $400{ }^{\circ} \mathrm{C}\left(752^{\circ} \mathrm{F}\right)$, and after rolling at $23^{\circ} \mathrm{C}$.

The hardness results are shown graphically in Figures 5 through 15. Figure 6 shows the effect of isothermal holding at $400{ }^{\circ} \mathrm{C}$. No significant hardness changes between $10,100,1000$, and 10,000 minutes were noted. However, a significant hardness difference was noted between zero time (i.e., as worked) and 10 minutes at temperature. The 25, 50, and 75-percent worked samples increased in hardness about 30 to $40 \mathrm{Knoop}$ hardness units. This effect was double checked on several samples and found to be reproducible. The cause of this more-or-less recovery-like hardness increase is unknown. Ignoring the recovery-like effect, one can say that aging does not occur at $400{ }^{\circ} \mathrm{C}$ at times up to one week.

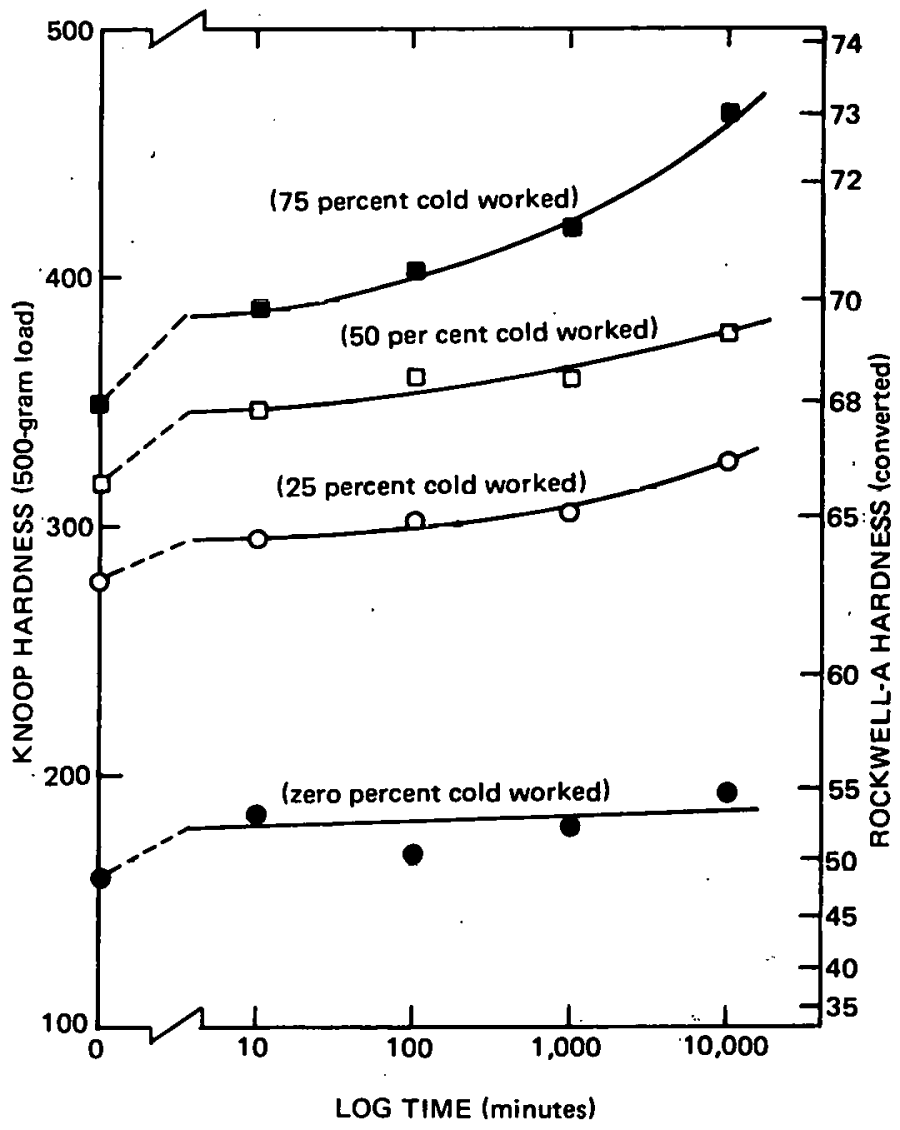

FIGURE 7. Knoop hardness values of worked and nonworked JBK-75 (1.85-weight percent titanium) after isothermal aging at $500{ }^{\circ} \mathrm{C}\left(932^{\circ} \mathrm{F}\right)$, and after rolling at $23^{\circ} \mathrm{C}$.

The recovery-like hardness change was also observed at $300^{\circ} \mathrm{C}$, however, significantly longer times were required. Figure 5 shows the effect of isothermal holding at $300^{\circ} \mathrm{C}$. At $300^{\circ} \mathrm{C}$, about 10,000 minutes were required to achieve the hardness. change that required 10 minutes at $400{ }^{\circ} \mathrm{C}$. Here again, as at $400^{\circ} \mathrm{C}$, the hardness change is thought due to recovery and not to a precipitation reaction.

Figure 7 shows hardness changes on aging the 0,25 , 50 , and 75 -percent worked samples at $500^{\circ} \mathrm{C}$. Significant aging does occur at $500^{\circ} \mathrm{C}$, especially in the cold-worked samples. The 75-percent worked sample was near maximum hardness after 1 week at $500^{\circ} \mathrm{C}$, while the 25 -percent worked sample was 


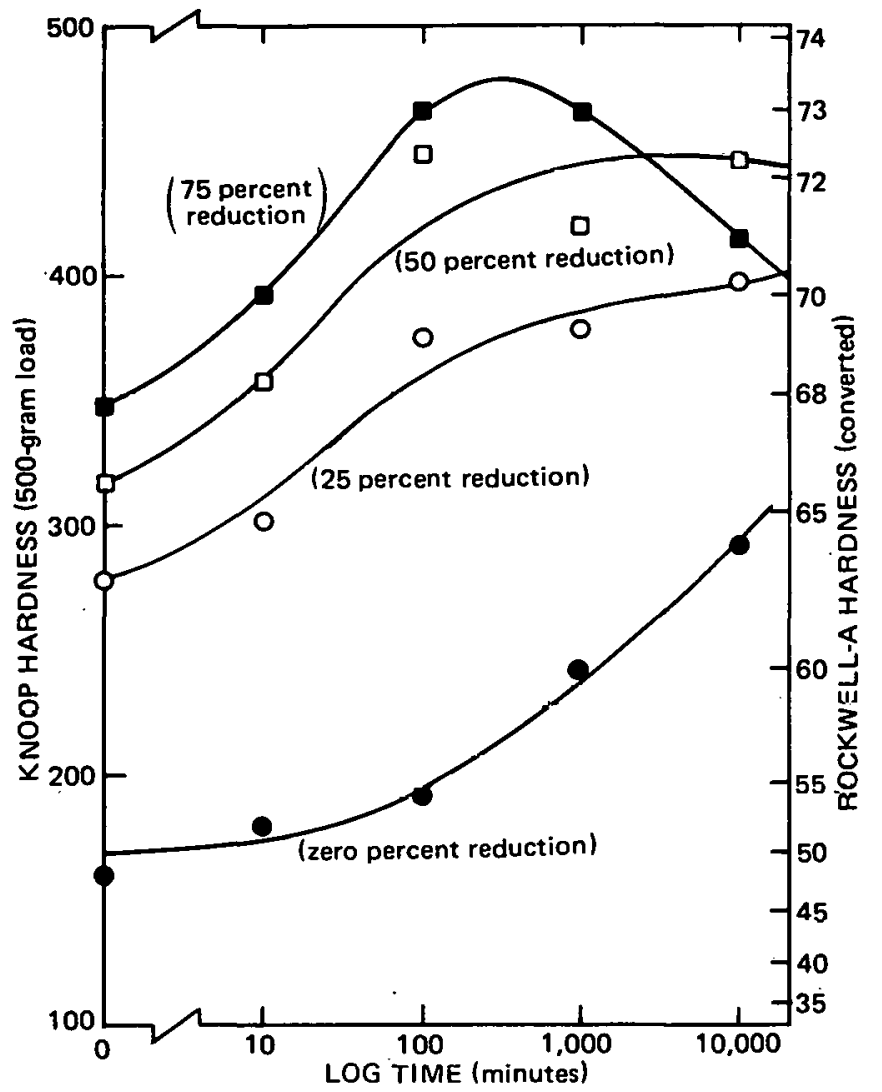

FIGURE 8. Knoop hardness values of worked and nonworked JBK-75 alloy (1.85-weight percent titanium) after isothermal aging at $600^{\circ} \mathrm{C}$ $\left(1112^{\circ} \mathrm{F}\right)$, and after rolling at $23^{\circ} \mathrm{C}$.

considerably underaged, and the 0-percent worked sample hardly aged at all; thus showing that cold working strongly influences precipitation kinetics. The athermal-like hardness increase noted at $400^{\circ} \mathrm{C}$ was also observed at $500^{\circ} \mathrm{C}$, but, here again, the cause was unknown.

The hardness changes on isothermal aging at $600^{\circ} \mathrm{C}$ are shown in Figure 8. Maximum hardness was reached in the 75-percent worked sample at about 6 hours, while the 50 -percent worked sample was near maximum hardness after 7 days. The 25 and 0 -percent worked samples were considerably underaged after 7 days at $600^{\circ} \mathrm{C}$. Maximum hardness on aging at $600^{\circ} \mathrm{C}$ was about $73.5 \mathrm{R}_{\mathrm{A}}$ for 75 percent work and $72.5 \mathrm{R}_{\mathrm{A}}$ for 50 percent work.

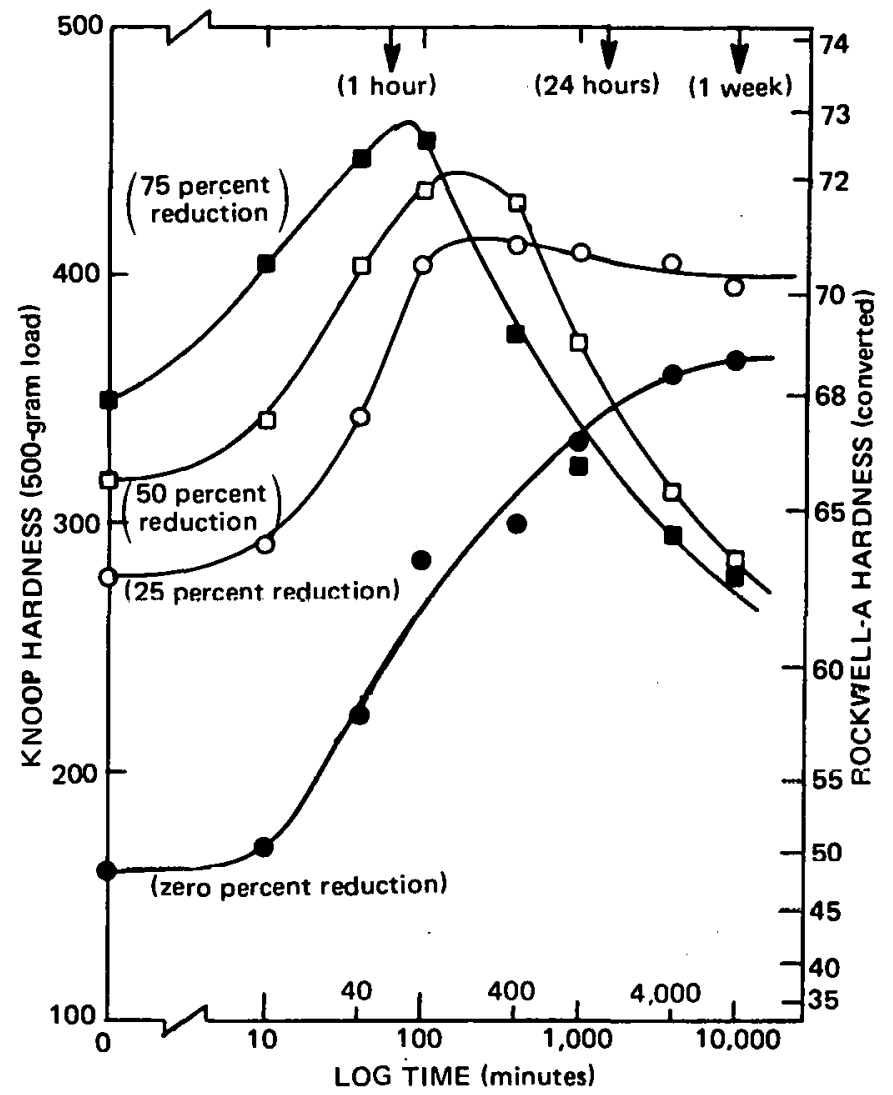

FIGURF 9. Knnnp hardness values of worked and nonworked JBK-75 alloy (1.85-weight percent titanium) after isothermal aging at $650^{\circ} \mathrm{C}$ $\left(1202{ }^{\circ} \mathrm{F}\right)$, and after rolling at $23{ }^{\circ} \mathrm{C}$.

The hardness changes on aging at $650^{\circ} \mathrm{C}$ are shown in Figure 9. Maximum hardness in the 75-percent worked sample was achieved in about one hour and was about $R_{A} 73$. Maximum hardness for the 50-percent worked material was obtained at about 3 hours and was near $R_{A} 72$. For the 25-percent worked alloy, maximum hardness was $\mathrm{R}_{\mathrm{A}} 71$ and required about 5 hours. The 0-percent worked sample was approaching a maximum hardness of $R_{A} 69$ after 1 week.

The effects on hardness after aging at $700{ }^{\circ} \mathrm{C}$ are shown in Figure 10. For the 75-percent worked metal, a hardness maximum of $\mathrm{R}_{\mathrm{A}} 72.5$ was achieved at about 30 minutes. The 50-percent worked alloy took about 60 -minutes to reach a maximum 


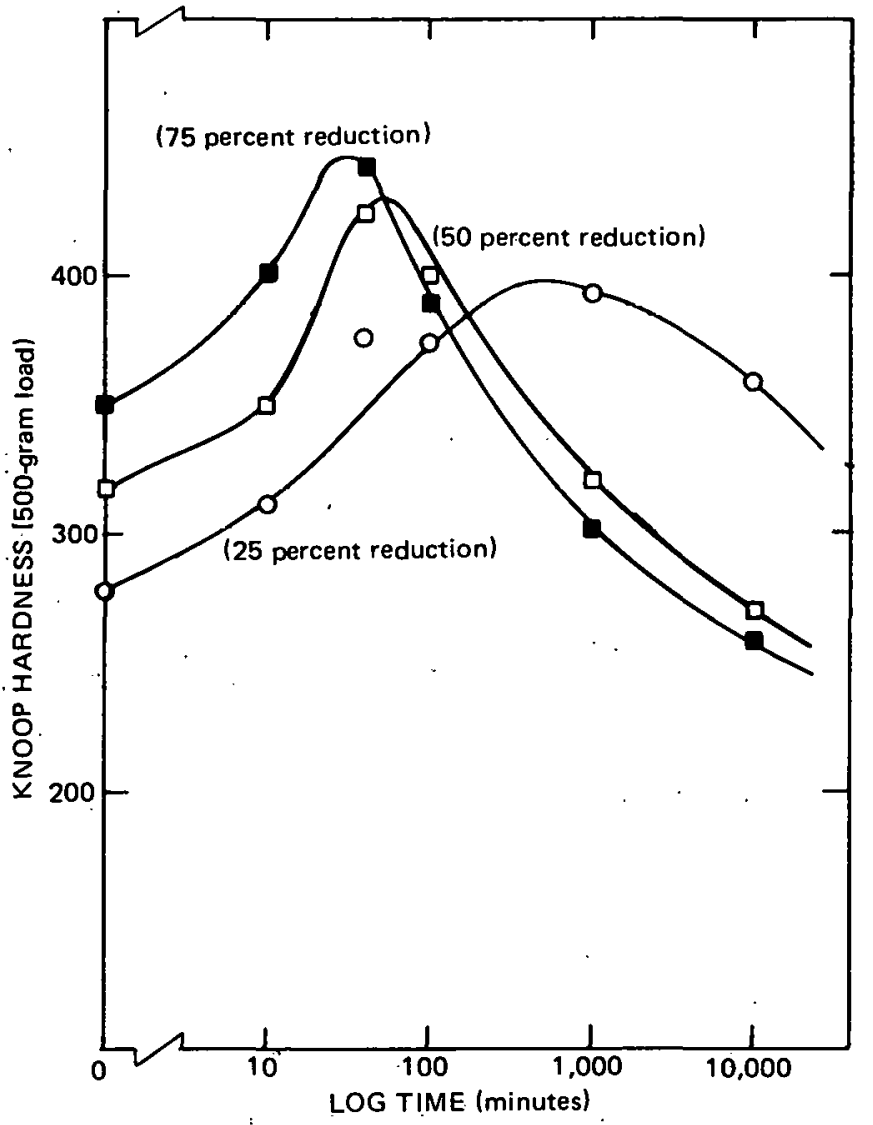

FIGURE 10. Knoop hardness values of worked JBK-75 alloy (1.85-weight percent titanium) after isothermal aging at $700{ }^{\circ} \mathrm{C}\left(1292{ }^{\circ} \mathrm{F}\right)$, and after rolling at $23^{\circ} \mathrm{C}$.

hardness of $\mathrm{R}_{\mathrm{A}}$ 71.5; while the 25-percent worked sample reached a maximum hardness of $\mathrm{R}_{\mathrm{A}} 70.5$ after about 6 hours.

Aging at $800{ }^{\circ} \mathrm{C}$ (Figure 11) showed the 25, 50, and 75-percent worked samples to all be overaged after 100 minutes. At times of 10,100, and 1000 minutes the 75-percent worked sample was softer than the 50 and 25-percent worked samples, respectively. After 10,000 minutes, all three worked conditions had the same hardness of $R_{A} 56$, which is well above the full soft condition of $R_{A} 43$.

The effects on hardness after aging at $850^{\circ} \mathrm{C}$ are shown in Figure 12. The 0, 25, 50, and 75-percent worked samples were all overaged after 100 minutes at $850^{\circ} \mathrm{C}$. After 10,000 minutes, the

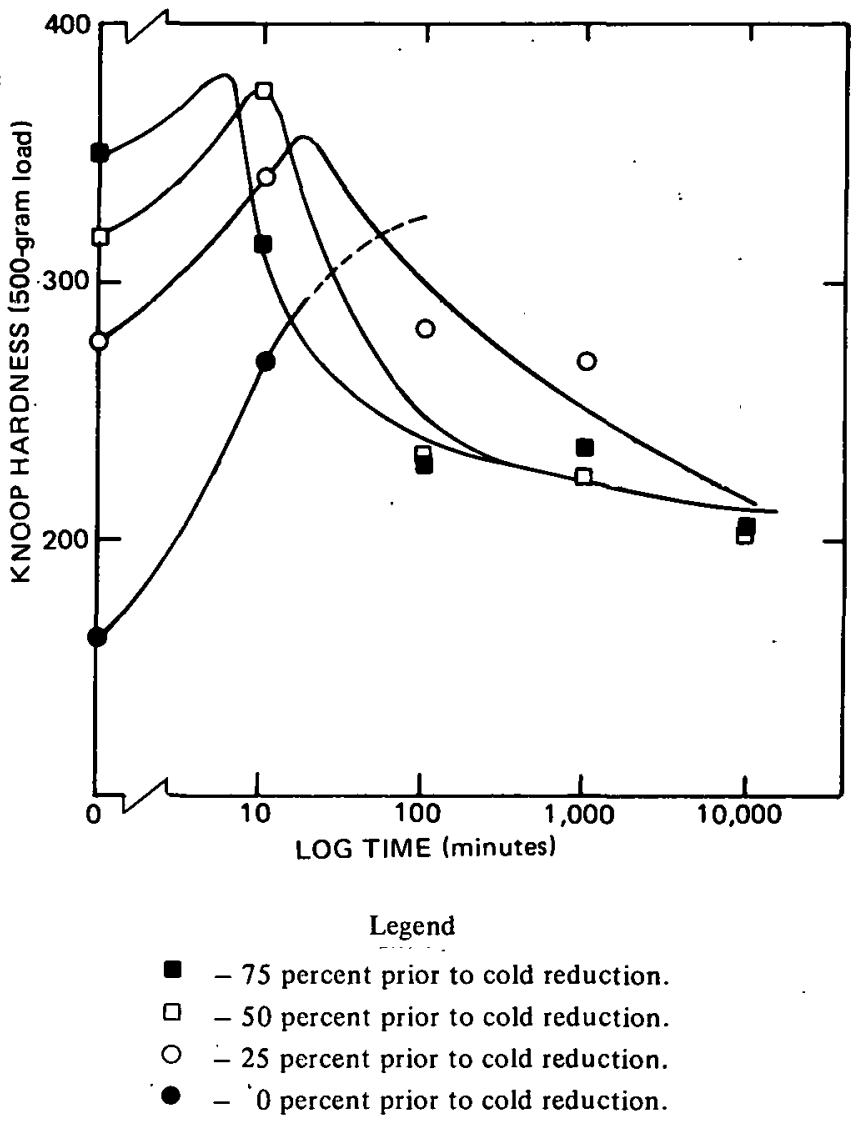

FIGURE 11. Knoop hardness values of worked JBK-75 alloy (1.85-weight percent titanium) after isothermal aging at $800{ }^{\circ} \mathrm{C}\left(1472{ }^{\circ} \mathrm{F}\right)$, and after rolling at $23^{\circ} \mathrm{C}$.

order of softness was 0,75 to 50 (tied), and 25 percent. The three worked samples after 10,000 minutes had hardness values well above the full soft condition.

Heating treating at 900,1000 , and $1100^{\circ} \mathrm{C}$ (Figures 13,14 , and 15 , respectively) resulted in a highly overaged (i.e., solutionized) condition for all cases. Minimum softness obtained at 900, 1000, and $1100^{\circ} \mathrm{C}$ was about $R_{A} 46, R_{A} 45$, and $R_{A} 43$, respectively.

\section{CONCLUSIONS}

1. Quench rate has a small effect on hardness. The water-quenched alloy was softest (158 


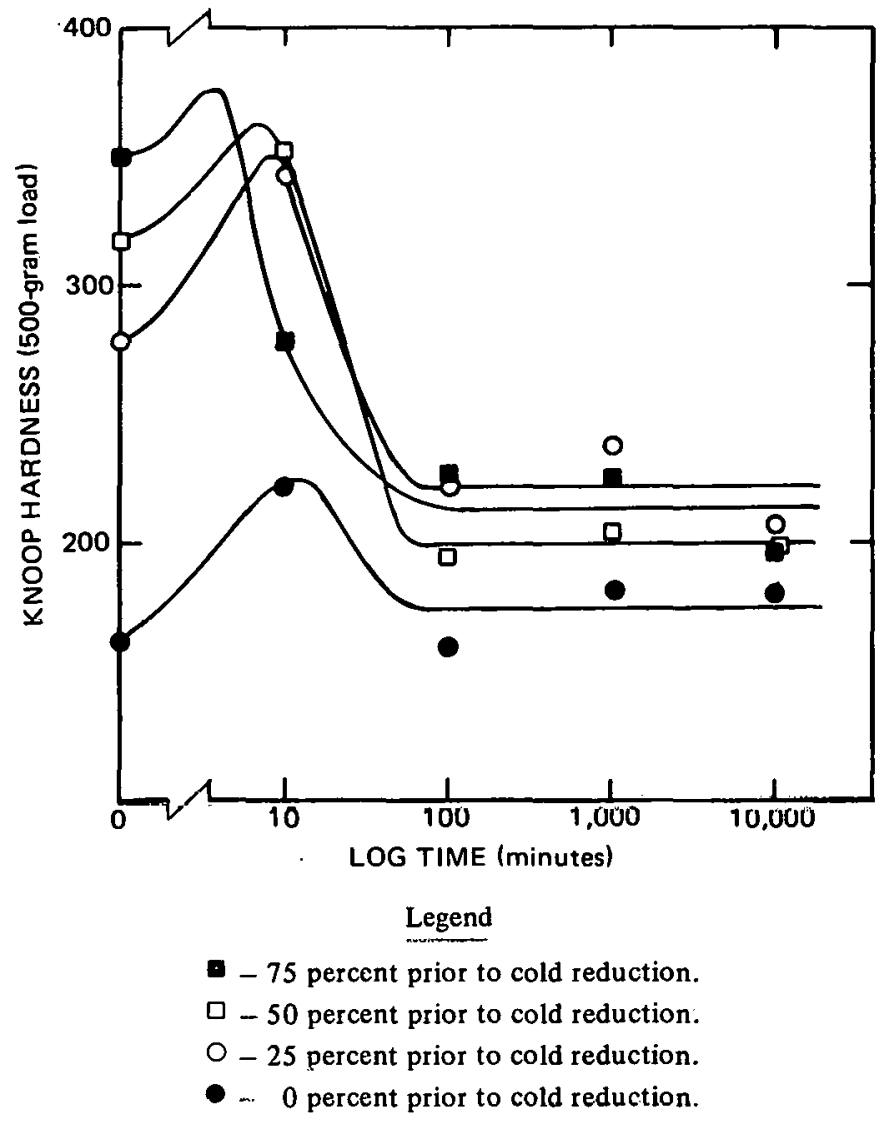

FIGURE 12. Knoop hardness values of worked and nonworked JBK-75 alloy (1.85-weight percent titanium) after isothermal aging at $850^{\circ} \mathrm{C}$ $\left(1562{ }^{\circ} \mathrm{F}\right)$, and after rolling at $23^{\circ} \mathrm{C}$.

Knoop or $R_{A} 48.5$ ), the oil-quenched alloy was intermediate in hardness (160 Knoop or $\mathrm{R}_{\mathrm{A}}$ 49.0), while the air-quenched material was hardest (164 or $\left.\mathrm{R}_{\mathrm{A}} 49.5\right)$.

2. In small bars [ 2.5 by 2.5 by $1.3 \mathrm{~cm}(1.0$ by 1.0 by 0.5 inches)], a significant hardness gradient is not developed on air, oil, or water quenching. Larger bars [ 3.3 by 1.3 by $20 \mathrm{~cm}(1.3$ by 0.5 by 8.0 inches)] did show a measurable but small hardness gradient.

3. Solutionizing temperature has a moderate effect on hardness. Samples solutionized at 900, 1000, and $1100^{\circ} \mathrm{C}$ gave values of 150,141 , and $134-$ Knoop, respectively, or $46.5,44.5$, and $42.8 \mathrm{R}_{\mathrm{A}}$, respectively, after water quenching.

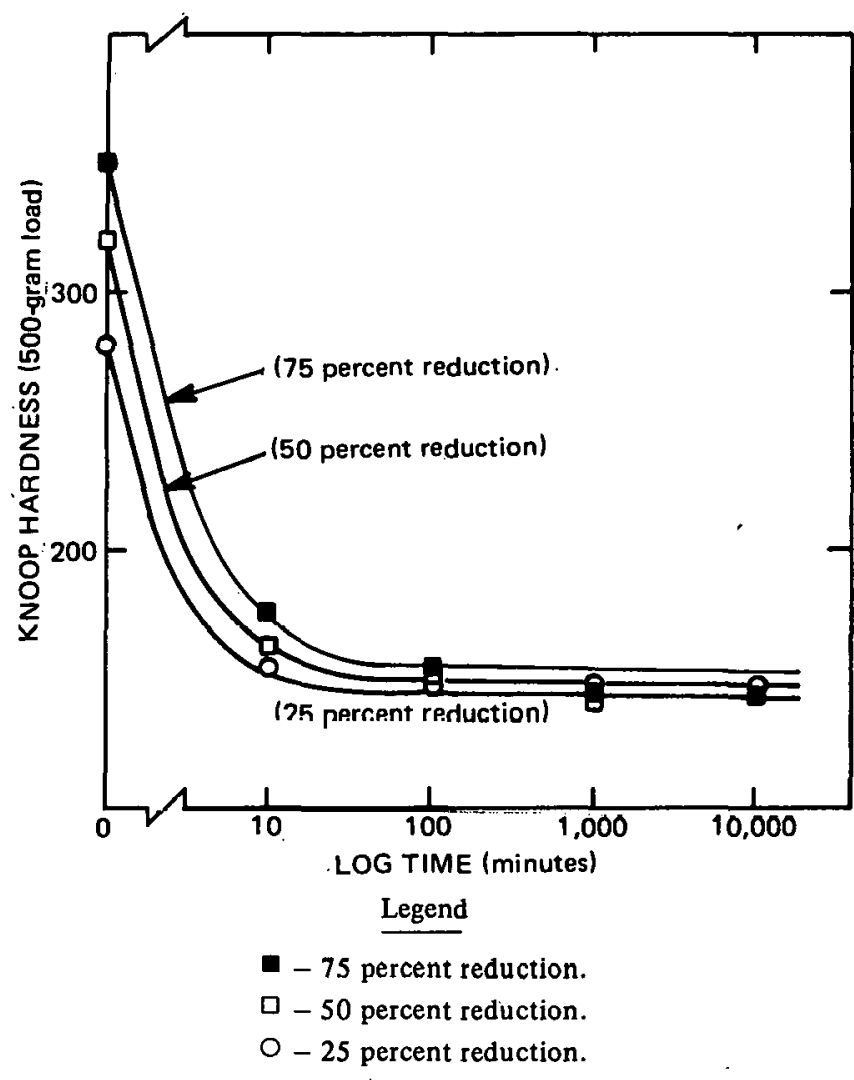

FIGURE 13. Knoop hardness values of worked JBK-75 alloy (1.85-weight percent titanium) after isothermal aging at $900{ }^{\circ} \mathrm{C}\left(1652{ }^{\circ} \mathrm{F}\right)$, and after rolling at $23^{\circ} \mathrm{C}$.

4. Solutionizing time (100 to 10,000 minutes) at 900,1000 , or $1100^{\circ} \mathrm{C}$ does not have a significant effect on the as-quenched hardness.

5. Temperature at $850^{\circ} \mathrm{C}\left(1562^{\circ} \mathrm{F}\right)$ is not an effective solutionizing one for JBK-75.

6. The JBK-75 can be significantly strengthened by cold working. Cold working alone produced hardness increases from Rockwell-A 49 (Knoop 160) to $R_{A} 68$ (Knoop 350).

7. A recovery-related hardness change is complete after 10,000 minutes at $300{ }^{\circ} \mathrm{C}$ or 10 minutes at $400{ }^{\circ} \mathrm{C}$ in both as-quenched and as-worked conditions.

8. Significant age hardening occurs at temperatures as low as $500^{\circ} \mathrm{C}$ for cold-worked material. 


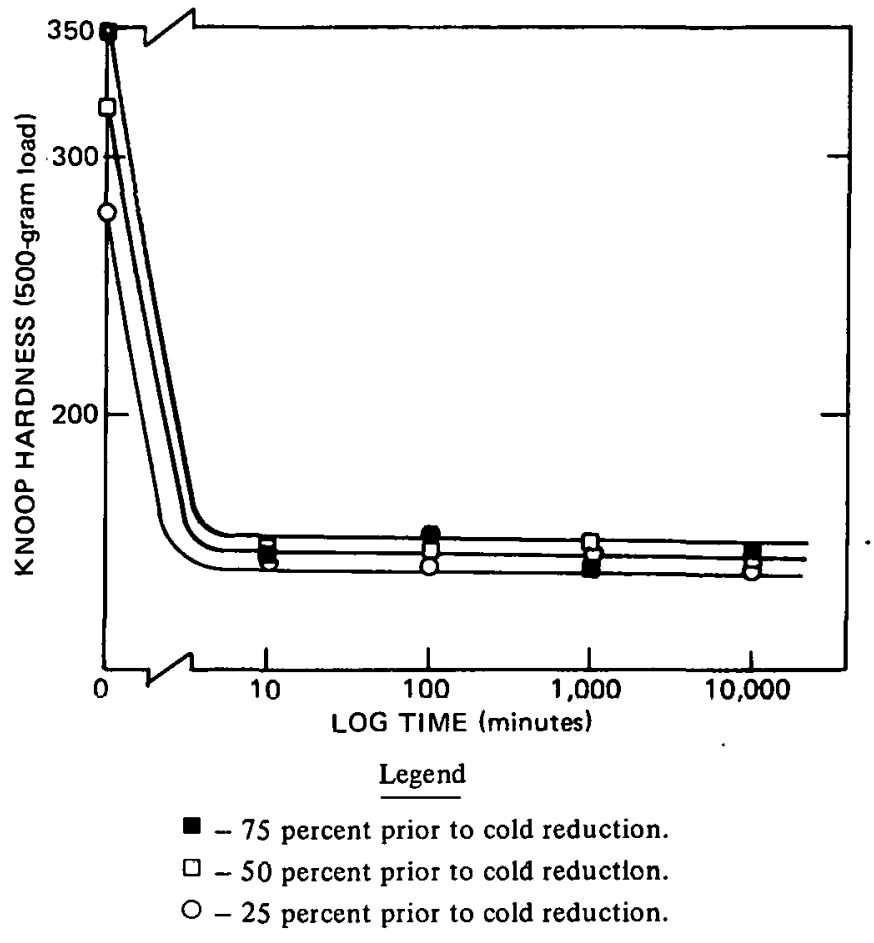

FIGURE 14. Knoop hardness values of worked JBK-75 alloy after isothermal aging at $1000{ }^{\circ} \mathrm{C}\left(1832^{\circ} \mathrm{F}\right)$.

9. Cold working is highly significant in accelerating the age-hardening reaction. A time factor of 10 to 100 is observed for the age-hardening reaction in as-worked versus nonworked material.

\section{REFERENCES}

1. I. A. Brooks and R. W. Krenzer. "Progress Toward a More Weldable A-286." Welding Journal Research Supplement 53:242-245. 1974.

2. J. A. Brooks. "Effect of Alloy Modifications on HAZ Cracking of A-286 Stainless Steel." Welding Journal Research Supplement 53:517.523. 1974.

3. K. J. Irvine, D. T. Llewellyn, and F. B. Pickering. "High-Strength Austenitic Stainless Steels." Journal of Iron Steel Institute 199:153-175. 1961.

4. R. F. Decker and S. Floreen. Precipitation from Substitutional Iron-Base Austenitic and

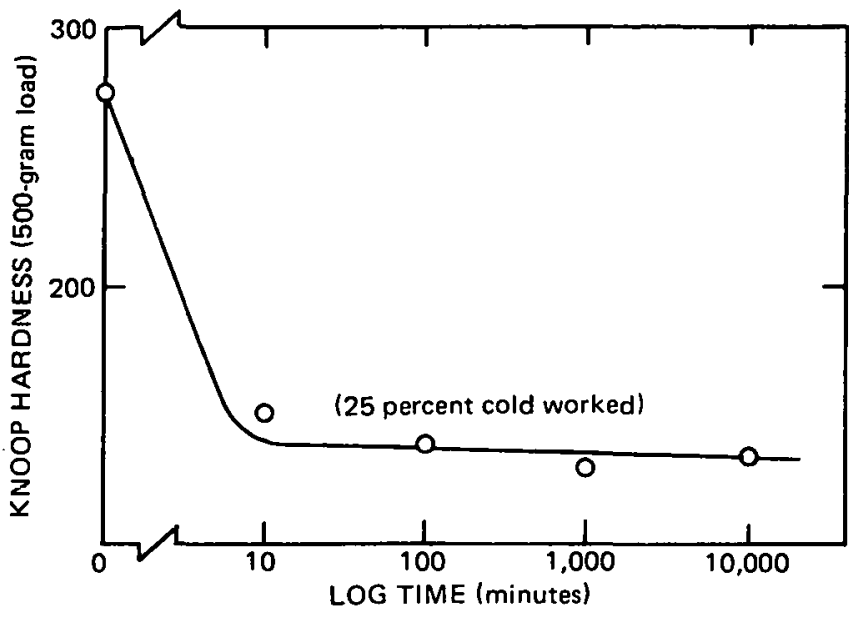

FIGURE 15. Knoop hardness values of worked JBK-75 alloy (1.85-weight percent titanium) after isothermal aging at $1100^{\circ} \mathrm{C}\left(2012^{\circ} \mathrm{F}\right)$, and after rólling at $23^{\circ} \mathrm{C}$.

Martensitic Solid Solutions. Gordon and Breach, New York. 1965. Pages 69-128.

5. R. B. Clark and F. B. Pickering. "Precipitation Effects in Austenitic Stainless Steels Containing Titanium and Aluminum Additions." Journal Iron Steel Institute 205:70-84. 1967.

6. A. W. Thompson. "Ductility Losses in Austenitic Stainless Steels Caused by Hydrogen." Hydrogen in Metals. American Society of Metals, Metals Park, Ohio. 1974. Pages 99-101.

7. Brooks and Krenzer. op. cit.

8. J. A. Brooks and R. W. Krenzer. "Weldable Age Hardenable, Austenitic Stainless Steel." U.S. Patent 3,895,939 to U.S. Energy Resources Development Agency, Washington, D.C. July 22, 1975 .

9. A. W. Thompson and J. A. Brooks. "Hydrogen Performance of Precipitation-Strengthened Stainless Steels Based on A-286." Metallurgical Transactions 6A:1431-1442. American Institute of Metallurgy Engineers. 1975.

10. G. L. Kehl. Principles of Metallographic Laboratory Practice. Third Edition. McGrawHill Book Company, Inc., New York. 1949. 
RFP-2492

THIS PAGE

\section{WAS INTENTIONALLY LEFT BLANK}

